\title{
Investigating surrogate cerebrospinal fluid matrix compositions for use in quantitative LC-MS analysis of therapeutic antibodies in the cerebrospinal fluid
}

\author{
Jens Rose Fogh ${ }^{1,2} \cdot$ Anne-Marie Jacobsen ${ }^{2} \cdot$ Tam T. T. N. Nguyen $^{1} \cdot$ Kasper D. Rand ${ }^{1} \cdot$ Line Rørbæk Olsen $^{2}$
}

Received: 16 August 2019 /Revised: 17 December 2019 / Accepted: 10 January 2020 / Published online: 1 February 2020

(C) The Author(s) 2020

\begin{abstract}
As quantitative analysis of biotherapeutics in cerebrospinal fluid (CSF) with LC-MS becomes increasingly widespread, there is a need for method developments towards higher sensitivity. By using artificial CSF (aCSF) in the development phase, the consumption of costly and sparsely available CSF can be limited. The aCSF compositions tested here were made from various dilutions of bovine serum albumin (BSA) or rat plasma to mimic the total protein concentration found in CSF. Focusing on monoclonal antibodies, the aCSF was spiked with human immunoglobulin (hIgG) and prepared with the bottom-up analysis technique using LC-MS. Assuming that the composition of the aCSF would affect the digest, the response from aCSF matrices was compared with CSF from rat, monkey, and dog in terms of estimated sample concentration and matrix effects. The samples were spiked with $\mathrm{hIgG}$ in the range of 10 to $1000 \mathrm{ng} / \mathrm{mL}$ and volumes of $10 \mu \mathrm{L}$ were transferred to sample preparation. The results indicate that BSA dilutions from 300 to $2000 \mu \mathrm{g} / \mathrm{mL}$ and rat plasma dilutions of $0.5-2 \%$ provide the most accurate concentration estimates when compared with rat CSF. $1000 \mu \mathrm{g} / \mathrm{mL}$ BSA did not produce significantly different concentration estimates for $500 \mathrm{ng} / \mathrm{mL}$ samples when compared with CSF from rat, monkey, and dog, and can therefore be used as aCSF for several different species.
\end{abstract}

Keywords Bioanalysis $\cdot$ Surrogate matrix $\cdot$ Liquid chromatography-mass spectrometry (LC-MS) $\cdot$ Monoclonal antibodies $(\mathrm{mAbs}) \cdot$ Cerebrospinal fluid (CSF)

\section{Introduction}

Within pharmaceutical research, there is considerable interest in therapeutic antibodies, with 9 out of the 20 best-selling drugs in 2018 being antibody-based [1]. Monoclonal antibodies (mAbs) have several attractive features including high specificity, longer half-life, and less side effects than traditional small-molecule drugs [2]. It does come at a price, as the sheer size and complexity of such mAbs can challenge

Electronic supplementary material The online version of this article (https://doi.org/10.1007/s00216-020-02403-3) contains supplementary material, which is available to authorized users.

Line Rørbæk Olsen

LIRO@lundbeck.com

1 Department of Pharmacy, University of Copenhagen, Universitetsparken 2, 2200 Copenhagen, Denmark

2 Translational DMPK, H. Lundbeck A/S, Ottiliavej 9, 2500 Valby, Denmark pharmacokinetic studies [3] and push analytical methods to their limits. This is especially true for mAbs developed to treat neurodegenerative diseases.

Examples of potential targets in neurodegenerative diseases are amyloid $\beta$ and tau proteins. In Alzheimer's and Parkinson's disease, they form neurotic plaques containing the aggregative amyloid $\beta \quad 1-42$ amino acid form [4-6] and neurofibrillary tangles with phosphorylated tau proteins $[7,8]$. Treatment of targets like these with therapeutic antibodies requires an estimation of $\mathrm{mAb}$ brain exposure to accurately study the effects in preclinical species. Direct quantification of brain material from experimental animals is often not feasible because of the risk of blood contamination as only approximately $0.1 \%$ of macromolecules cross the blood-brain-barrier (BBB) $[9,10]$. Requirement of brain material also prevents the method from being used in human studies and for repeated extractions from live animals. An alternative approach to estimate $\mathrm{mAb}$ levels in the brain is to quantify levels in cerebrospinal fluid (CSF) [11]. The dominating challenge in early drug research for quantitative analysis of $\mathrm{mAb}$ in CSF is the 
limited sample volume in preclinical species like mouse and rat and the need for a suitable surrogate CSF matrix. A generic screening method for $\mathrm{mAb}$ pharmacokinetics is needed for simultaneous quantitation of different proteins in the same small volume sample. Quantitative analysis using LC-MS offers both multiplexing and high sensitivity for a generic method; however, the need for a suitable surrogate CSF matrix remains.

Historically, quantitation of mAbs in CSF and plasma samples has been performed using ligand binding assay platforms (LBA) [12-14]. LC-MS stands as a complimentary technique to LBAs and offers the ability to quantify several proteins or peptides simultaneously and with a high degree of specificity [15]. In a preclinical setting with many different analytes of interest, such as protein biomarkers and blood contamination markers, it is beneficial with a short method development time as can be obtained with LC-MS along with the option of multiplexing [15]. LC-MS analysis of mAbs often uses the bottom-up strategy where denatured $\mathrm{mAb}$ is digested to produce signature peptides for a sensitive and robust analysis [16]. The sample preparation is influenced by matrix effect from lipids, proteins, and salts and the protease must be optimized to the total protein concentration in the sample for optimal digestion efficiency $[17,18]$. This method is applied on a routine basis for $\mathrm{mAb}$ in plasma samples [19-23], and though CSF appears as a cleaner matrix with less proteins and lipids (Table 1), some key differences must be noted, namely the low sample volume and complicated sample collection. While approximately $15 \mathrm{~mL}$ CSF can be collected from humans during a single sampling event [24], the situation is much different for animal species commonly used in preclinical drug development. The total volume of CSF in rats is around $90 \mu \mathrm{L}$ and in mice even less [25]. This greatly reduces the working volume of CSF samples and makes sample collection a challenging process with risk of blood contamination [26]. The limited volume makes classical sample preparation such as preconcentration by immunopurification or solid-phase extraction less feasible and requires sensitive analysis methods to

Table 1 Typical composition of human plasma and CSF [26, 29-31]

\begin{tabular}{lll}
\hline & CSF & Plasma \\
\hline Proteins $(\mu \mathrm{g} / \mathrm{mL})$ & $300-700$ & $60,000-70,000$ \\
-Albumin & 192 & 42,150 \\
-Globulins & 50 & 22,700 \\
-Transferrin & 14 & 2600 \\
-Fibrinogen & 0.6 & 2800 \\
Lipids $(\mu \mathrm{g} / \mathrm{mL})_{\mathrm{Na}^{+}(\mathrm{mmol} / \mathrm{L})}^{10-20}$ & 50,000 \\
$\mathrm{Cl}^{-}(\mathrm{mmol} / \mathrm{L})$ & $140-145$ & $135-147$ \\
$\mathrm{Glucose}(\mu \mathrm{g} / \mathrm{mL})$ & $115-120$ & $95-105$ \\
$\mathrm{pH}$ & 600 & 900 \\
\hline
\end{tabular}

detect drugs that only pass the BBB in low concentrations. Often, it is also of value to have multiple readouts from CSF, so disease biomarkers as well as mAbs can be quantified from the same sample $[24,27,28]$. It is therefore important that a viable surrogate matrix for CSF is found so optimized bottomup LC-MS methods can be developed for CSF matrices.

A standardized artificial CSF (aCSF) is needed as a surrogate matrix to develop and perform sensitive LC-MS methods for CSF without the need of sacrificing several animals to retrieve blank CSF. An aCSF must behave identically to CSF with regard to digestion efficiency when exposed to the bottom-up workflow. In addition, it must also mimic prevention of any non-specific binding (NSB) of analytes, as NSB to surfaces is an issue related to every process involving pipetting and storage of peptides and proteins [32, 33]. Finally, LCMS ion suppression must be accounted for although the use of a stable isotope-labeled (SIL) internal standard (ISTD) will correct this to some degree. In short, an aCSF must affect all stages of sample preparation and analysis to the same degree as real CSF.

Various aCSF compositions have already been applied in other labs and are summarized in Table 2. To our knowledge, no prior studies have been conducted to systematically investigate how the composition of an aCSF will impact results obtained from bottom-up LC-MS analysis of mAbs as outlined above. The purpose of the present work is to address this challenge and show which compositions of aCSF are suitable for imitating real CSF samples in a bottom-up LCMS workflow for quantitative mAb analysis.

\section{Materials and methods}

\section{Chemicals and reagents}

CSF from all species was purchased from Seralab (UK) and plasma was purchased from Cytotech (UK). SILu ${ }^{\text {TMLite }}$ SigmaMAb human immunoglobulin G1 (hIgG) standards,

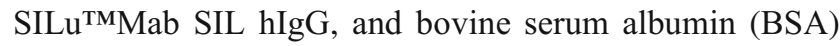
were obtained from Sigma-Aldrich (MO, USA).

ProteinWorks eXpress Digest kit (Waters, MA, USA) was used for the bottom-up workflow. The kit includes all reagents used in the digestion workflow (Table 3) except for ultrapure water (MQ) which is produced in-house on a Millipore Synergy UV system (Merck, Germany). HPLC-grade acetonitrile and ammonium bicarbonate were purchased from Merck (Germany).

\section{Calibration standards, control samples, and surrogate matrices}

The surrogate matrices were produced from either diluted rat plasma or BSA. In total, 11 surrogate matrices were prepared 
Table 2 A list of surrogate matrices used in other studies. Perfusion fluid is a term used for describing commercially available substitutes for CSF with similar ionic composition and no protein content

\begin{tabular}{lll}
\hline Author or publication & aCSF type & Application \\
\hline Lame et al. [34] & $5 \%$ rat plasma in perfusion fluid & Amyloid peptide quantitation \\
Dillen et al. [35] & $0.15 \%$ bovine serum albumin in perfusion fluid & Amyloid peptide quantitation \\
Hooshfar et al. [30] & $0.5-17 \%$ rat plasma and perfusion fluid & Small-molecule drug quantitation \\
Barthélemy et al. [36] & $0.5 \%$ rat serum & Tau protein quantitation \\
Oe et al. [37] & $0.15 \%$ human serum albumin in perfusion fluid & Amyloid peptide quantitation \\
Oeckl et al. [38] & $340-1000 \mu \mathrm{g} / \mathrm{mL}$ human serum albumin in perfusion fluid & Quantitation of synuclein species \\
Goda et al. [39] & Perfusion liquid [40] & Small-molecule drug quantitation \\
\hline
\end{tabular}

in $50 \mathrm{mM}$ ammonium bicarbonate (AB50) for the following concentrations: $20,300,600,1000,1400,2000$, and $10,000 \mu \mathrm{g} / \mathrm{mL}$ BSA and $0.5,1,2$, and $5 \%$ rat plasma (in the following, referred to as "surrogate matrix").

Eight hIgG standards were prepared in the concentration range $20-20,000 \mathrm{ng} / \mathrm{mL}$ in AB50 with $20 \mu \mathrm{g} / \mathrm{mL}$ BSA and diluted 1:19 in surrogate matrix by liquid handling robot (Hamilton Robotics, NV, USA) for a final calibration standard range of $1-1000 \mathrm{ng} / \mathrm{mL}$.

Manually prepared control and CSF samples were made by spiking hIgG (prepared in AB50 with $20 \mu \mathrm{g} / \mathrm{mL}$ BSA) in surrogate matrix or CSF in the ratio 1:9. Final samples were stored at $-80{ }^{\circ} \mathrm{C}$ until use.

\section{Instrumentation}

All analytical work was carried out using Acquity UPLC system (Waters, MA, USA) coupled with Xevo TQ-XS or Xevo TQ-S triple quadrupole (Waters, MA). Separation was performed using an Acquity CSH C18 Column, $130 \AA \AA, 1.7 \mu \mathrm{m}$, $2.1 \times 100 \mathrm{~mm}$ (Waters, MA). Sample handling was performed in protein LoBind plates and tubes (Eppendorf, Germany) with low-retention pipette tips (Mettler Toledo, Switzerland).

\section{Sample preparation}

Quantitation by measuring selected tryptic peptides from hIgG was done following the bottom-up approach as outlined in Table 3. SILu ${ }^{\mathrm{TM} M a b}$ was added at protein level as ISTD in $20 \mu \mathrm{g} / \mathrm{mL}$ BSA to reduce NSB in the digestion tubes. The hIgG samples stored in a freezer were then thawed and added to the tubes. Samples were prepared according to the instructions found in ProteinWorks with some modifications to adjust for the reduced protein concentration in CSF compared with plasma (see Table 3). Reduction and alkylation agents were used in $10 \mu \mathrm{L}$ and $15 \mu \mathrm{L}$ volumes respectively. Trypsin was diluted $1: 1$ in digestion buffer and $15 \mu \mathrm{L}$ was added to each sample. Samples were denatured for $10 \mathrm{~min}$ at $80^{\circ} \mathrm{C}$ and reduction was performed at $60{ }^{\circ} \mathrm{C}$ for $20 \mathrm{~min}$. The alkylation at room temperature over $30 \mathrm{~min}$ was followed by digestion for $2 \mathrm{~h}$ at $45^{\circ} \mathrm{C}$. The digestion was quenched by acidifying the samples over $15 \mathrm{~min}$ at $45{ }^{\circ} \mathrm{C}$ and finally the samples were centrifuged for $20 \mathrm{~min}$ at $5{ }^{\circ} \mathrm{C}$ at 1800 RCF. Seventy microliters of supernatant from each sample was transferred to a 96-well plate and mixed with $40 \mu \mathrm{L}$ 50:50 water:acetonitrile.

Table 3 Sample preparation as modified from the protocol found in the ProteinWorks kit

\begin{tabular}{|c|c|c|}
\hline Step & Experimental & Purpose \\
\hline Preparation & $\begin{array}{l}40 \mu \mathrm{L} \text { digestion buffer with } 300 \mathrm{ng} / \mathrm{mL} \mathrm{SILu}^{\mathrm{TM} M a b} \text { ISTD and } \\
20 \mu \mathrm{g} / \mathrm{mL} \text { BSA is added to each tube followed by } 10 \mu \mathrm{L} \text { sample }\end{array}$ & $\begin{array}{l}\text { Addition of internal standard and reduction of non-specific } \\
\text { binding }\end{array}$ \\
\hline Denaturation & Sample and internal standard is denatured for $10 \mathrm{~min}$ at $80^{\circ} \mathrm{C}$. & Unfolding of the protein \\
\hline Reduction & Addition of $10 \mu \mathrm{L}$ reduction agent and heating for $20 \mathrm{~min}$ at $60{ }^{\circ} \mathrm{C}$ & $\begin{array}{l}\text { Reduction of the cysteine bonds to make the protein accessible } \\
\text { to digestion }\end{array}$ \\
\hline Alkylation & $\begin{array}{l}\text { Addition of } 15 \mu \mathrm{L} \text { alkylation agent and covered from light for } 30 \\
\text { min at room temperature }\end{array}$ & $\begin{array}{l}\text { Alkylation of the thiol groups to prevent cysteine bonds from } \\
\text { reforming }\end{array}$ \\
\hline Digestion & Addition of $15 \mu \mathrm{L}$ trypsin and heating for $2 \mathrm{~h}$ at $45^{\circ} \mathrm{C}$ & Cleavage of the protein to generate signature peptides \\
\hline Quench & $\begin{array}{l}\text { Addition of } 5 \mu \mathrm{L} \text { digestion inactivation agent and heating for } 15 \\
\text { min at } 45^{\circ} \mathrm{C} \text { followed by } 20 \text { min centrifugation at } 1800 \mathrm{RCF} \text { at } 4{ }^{\circ} \mathrm{C}\end{array}$ & Decreasing the $\mathrm{pH}$ to quench the enzymatic activity of trypsin \\
\hline
\end{tabular}




\section{Chromatography and MS}

The peptides were separated using 12-min gradient elution on a UPLC system with a $20 \mu \mathrm{L}$ sample loop. Mobile phase A was MQ water with $0.1 \%$ formic acid and mobile phase $B$ was acetonitrile with $0.1 \%$ formic acid (Table 4). Analysis was performed in selected reaction monitoring (SRM) mode with each signature peptide and its SIL equivalent being monitored simultaneously. Signature peptides and their respective acquisition settings are shown in Table 5 and represent different polarity, sizes, and charge states. SIL peptides for ISTD were of identical sequence and used the same method settings (transitions found in the Electronic Supplementary Material, ESM). All signature peptides have been found to be stable for at least $24 \mathrm{~h}$ at $4{ }^{\circ} \mathrm{C}$ in a autosampler despite containing oxidation prone amino acids like methionine and tyrosine. Peak area was determined and normalized with ISTD using TargetLynx quantitation software (Waters, MA). Further data treatment and statistical analysis not supported by TargetLynx were performed in GraphPad Prism 7 (GraphPad Software, CA, USA).

\section{Experiment setup}

The setup was designed around three experiments in order to investigate which surrogate matrices could be recommended for use in quantitative analysis of CSF from preclinical species. All the experiments were performed using the bottom-up approach described in the "Sample preparation" section and, except for the species difference evaluation, estimates were based on the ALPAPIEK 419-654 signature peptide with the remaining peptides in Table 5 used for validation.

First, the ion suppression and digestion efficiency were investigated using the ISTD response from SIL peptides added to the digestion tubes as intact protein in a relatively large amount. From the procedure in Table 3, $40 \mu \mathrm{L} 300 \mathrm{ng} /$ $\mathrm{mL}$ SIL standard was added to four replicates in the six different matrices plus CSF (rat) and five transitions were

Table 4 Time points and compositions for the UPLC gradient used for all experiments. $0.1 \%$ formic acid was added to both mobile phases

\begin{tabular}{lll}
\hline Time (min) & $\mathrm{A}\left(\mathrm{H}_{2} \mathrm{O}\right)(\%)$ & $\mathrm{B}(\mathrm{ACN})(\%)$ \\
\hline 0 & 98 & 2 \\
2 & 98 & 2 \\
8 & 70 & 30 \\
8.5 & 10 & 90 \\
9.5 & 10 & 90 \\
10 & 98 & 2 \\
12 & 98 & 2 \\
\hline
\end{tabular}

monitored simultaneously. By summing the response from each signature peptide normalized to CSF, the average matrix effect from each surrogate matrix can be assessed. If any of the surrogate matrices cause significant ion suppression or reduced digestion efficiency compared with CSF, it will result in a lower signal for the SIL peptides.

The second experiment was designed to evaluate the accuracy and precision of QC samples in different surrogate matrices to determine if factors other than ion suppression and digestion efficiency could affect the estimates. Nine different surrogate matrices were spiked with hIgG at 3 levels $(10,100$, and $1000 \mathrm{ng} / \mathrm{mL}$ ) in 4 replicates and estimated using one calibration curve in $1000 \mu \mathrm{g} / \mathrm{mL}$ BSA. Spiked rat CSF was used as a reference.

The last experiment evaluated species differences using a surrogate matrix of $1000 \mu \mathrm{g} / \mathrm{mL}$ to estimate concentrations of QC samples spiked into CSF from dog, rat, and monkey. This experiment would determine if an aCSF could be used for multiple species and provide an accurate estimate. QC samples of 500 and $1000 \mathrm{ng} / \mathrm{mL}$ in 4 replicates were estimated using GPSVFPLAPSSK 418-506 and TTPPVLDSDGSFFLYSK 937-836 signature peptides to reduce interference from endogenous peptides.

\section{Results and discussion}

\section{Calibration curves for quantitation}

Human $\operatorname{IgG}$ is considered a suitable analyte for evaluation of $\mathrm{aCSF}$ as it produces stable signature peptides of different sizes and hydrophobicity (chromatogram shown in ESM) that can be affected differently by the tested matrices. The hIgG concentration was estimated using calibration curves made in $1000 \mu \mathrm{g} / \mathrm{mL}$ BSA. The statistical data from the linear regression on each fragment is shown in Table 6. Selected peptides allowed calibration ranges of $1-1000 \mathrm{ng} / \mathrm{mL}$ with no data points deviating more than $20 \%$ from the model. Rat CSF and BSA show no interference with the signature peptides in Table 5 as tested experimentally (see ESM) and with a BLAST search. The ALPAPIEK 419-654 peptide was chosen for quantitation of all samples (unless otherwise stated) while the other peptides were used for validation. In general, the method performed well and allowed reliable quantitation of samples with $10 \mathrm{ng} / \mathrm{mL}$ in $10 \mu \mathrm{L}$ volumes of rat CSF.

\section{Matrix effect on internal standard response}

Six surrogate matrices covering a broad range of protein content were investigated for their matrix effect on the ISTD signal. Each bar displayed in Fig. 1 represents the response from all signature peptides normalized to CSF $(=100 \%)$. By using multiple transitions from peptides with different 
Table 5 Signature peptides with their respective settings as used in SRM for the quantitation of hIgG. Position is referring to the SILu ${ }^{\mathrm{TM}} \mathrm{Lite}$ hIgG sequence at the constant region of the heavy chain $\left(\mathrm{H}_{\mathrm{C}}\right)$. The ISTD equivalents can be found in the ESM

\begin{tabular}{|c|c|c|c|c|c|c|}
\hline Peptide & Amino acid position & Precursor $(m / z)$ & Fragments $(m / z)$ & Dwell time (ms) & Collision energy (eV) & Cone voltage $(\mathrm{V})$ \\
\hline ALPAPIEK & $331-338 \mathrm{H}_{\mathrm{C}}$ & 419.76 & $\begin{array}{l}654.38 \\
486.29\end{array}$ & $\begin{array}{l}59 \\
59\end{array}$ & $\begin{array}{l}11 \\
20\end{array}$ & $\begin{array}{l}20 \\
20\end{array}$ \\
\hline DTLMISR & $253-259 \mathrm{H}_{\mathrm{C}}$ & 418.22 & 506.28 & 59 & 17 & 20 \\
\hline GPSVFPLAPSSK & $126-137 \mathrm{H}_{\mathrm{C}}$ & 593.83 & 699.40 & 80 & 21 & 40 \\
\hline VVSVLTVLHQDWLNGK & $306-321 \mathrm{H}_{\mathrm{C}}$ & 603.34 & 805.44 & 68 & 20 & 20 \\
\hline TTPPVLDSDGSFFLYSK* & $397-413 \mathrm{H}_{\mathrm{C}}$ & 937.46 & 836.42 & 16 & 20 & 20 \\
\hline
\end{tabular}

*Only used when comparing different species because of low interference from endogenous peptides

properties, the average matrix effect can be assessed. A one-way ANOVA determined that two of the matrices produced significantly lower responses $(p<0.05)$ than observed in CSF (mean peak areas and $p$ values are shown in ESM). The two matrices, $10,000 \mu \mathrm{g} / \mathrm{mL} \mathrm{BSA}$ and $5 \%$ plasma ( $3000 \mu \mathrm{g} / \mathrm{mL}$ total protein), had the highest protein content of the tested matrices. It is likely that the reduced response was caused either by ion suppression or by decreased digestion efficiency; hence, the high protein concentration matrices cannot be recommended to use as a surrogate for CSF. However, the $10,000 \mu \mathrm{g} / \mathrm{mL}$ BSA matrix was analyzed further to determine if ISTD is capable of correcting the reduced signal observed. The remaining matrices produced similar responses so any variation observed for the hIgG analyte in the following experiments was likely caused by factors other than ion suppression and digestion efficiency. The $1000 \mu \mathrm{g} / \mathrm{mL}$ BSA matrix showed the closest resemblance to rat CSF so this was chosen as the default calibration curve.

\section{Comparison of aCSF compositions}

Nine different surrogate matrices were evaluated by spiking with three levels of $\operatorname{LgG}(10,100,1000 \mathrm{ng} / \mathrm{mL})$ and comparing the estimates with similar samples in rat CSF. The results, including coefficient of variation and accuracy, are listed in Table 7. The majority of the spiked samples was within $\pm 20 \%$ accuracy relative to the $1000 \mu \mathrm{g} / \mathrm{mL}$ BSA calibration curve and is therefore considered to show acceptable performance as surrogate matrices. One exception was the $20 \mu \mathrm{g} / \mathrm{mL}$ BSA matrix with less than $80 \%$ accuracy which is therefore considered unsuitable as a surrogate matrix. The total content of protein in the $20 \mu \mathrm{g} / \mathrm{mL}$ BSA is considerably lower than that in the other tested matrices and the lower response observed in this matrix may possibly be due to increased NSB during sample handling and preparation. The ISTD signal from the same samples was not affected, which indicates that the loss must have occurred during storage and handling prior to the bottom-up method.

The range of total protein content in the remaining matrices $(300-10,000 \mu \mathrm{g} / \mathrm{mL}$ protein) is likely to cover biological variations of real CSF samples. Even the $10,000 \mu \mathrm{g} / \mathrm{mL}$ BSA matrix provided similar accuracy as the other matrices and could work as an aCSF, but it should be noted that the overall decreased signal caused by the large amount of protein can decrease sensitivity and increase column wear. Also, it was only possible to achieve this accuracy because a SIL signature peptide was available. A novel biotherapeutic with a unique sequence cannot rely on available SIL signature peptides. These results demonstrate the importance of the total protein concentration in the matrix since this will significantly affect the estimated concentration of a hIgG analyte. The protein content needs to be above a level where NSB is avoided
Table 6 Key data for the calibration curves generated and used to estimate sample concentrations. SIL versions of the same peptides were used as internal standard for all experiments

\begin{tabular}{llllll}
\hline Peptide & Fragment $(m / z)$ & $\begin{array}{l}\text { Calibration curve } \\
\text { range }(\mathrm{ng} / \mathrm{mL})\end{array}$ & Weighting & Linear fit $\left(r^{2}\right)$ & Slope \\
\hline ALPAPIEK & 654.38 & $1-1000$ & $1 / x$ & 0.9996 & 0.00152 \\
& 486.29 & $1-1000$ & $1 / x$ & 0.9999 & 0.00148 \\
DTLMISR & 506.28 & $10-1000$ & $1 / x$ & 0.9992 & 0.00204 \\
GPSVFPLAPSSK & 699.40 & $50-1000$ & $1 / x$ & 0.9974 & 0.00144 \\
VVSVLTVLHQDWLNGK & 805.45 & $50-1000$ & $1 / x$ & 0.9997 & 0.00153 \\
TTPPVLDSDGSFFLYSK & 836.42 & $10-1000$ & $1 / x$ & 0.9990 & 0.00128 \\
\hline
\end{tabular}




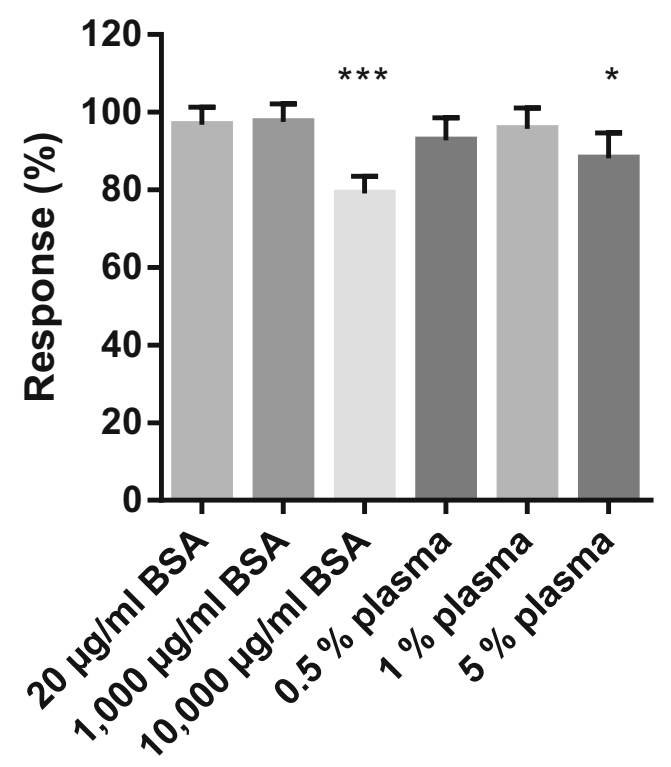

Fig. 1 Comparison of the response from internal standard in 6 different matrices. The mean response from at least 4 replicates of 5 different fragments is normalized to the results from internal standard in rat CSF. Mean values significantly different from those obtained in the CSF matrix are marked with one asterisk for $p<0.01$ and three asterisks for $p<0.0001$

but below a level where it does not affect digestion efficiency or cause ion suppression in the MS analysis as seen in Fig. 1. Seemingly, CSF contained enough protein to prevent any observable NSB of the hIgG analyte. The coefficient of variation was below $10 \%$ for 28 out of the 32 replicates and provides a good measure of the robustness of the bottom-up method used.

Although $300-10,000 \mu \mathrm{g} / \mathrm{mL}$ BSA and $0.5-2 \%$ plasma all performed well as a surrogate matrices for CSF, there are some considerations to take into account. BSA from a standardized production is expected to give less batch variation due to the relatively homogenous content. There is less chance of the matrix containing any proteins or proteases that can affect the analyte of interest which assures a similar effect across different analytes. Diluted plasma is under influence from the species of origin, diet, and other factors [41] and has different protein concentrations and compositions across individual donors. However, diluted plasma consists of a large variety of proteins and other components and can behave more realistically with regard to interferences during analysis or, if needed, immunocapture. In either case, the biological matrix must be examined for any protein sequence overlap with the analyte or identical fragmentation patterns during analysis by MS. For a more general purpose than hIgGs, BSA has the advantage that the risk of finding endogenous peptides or proteins is low, and therefore, BSA may be well suited for, e.g., biomarker quantitation using LC-MS.
Comparison of aCSF with CSF from preclinical species

Two levels of hIgG in CSF from three species were estimated using a single surrogate matrix. Results shown in Fig. 2 are based on peptides GPSVFPLAPSSK (GPSV) and TTPPVLDSDGSFFLYSK (TTPP) to provide common signature peptides for all three species. The results show that $1000 \mu \mathrm{g} / \mathrm{mL}$ BSA performs well as aCSF for rat, dog, and monkey by producing estimates within $\pm 20 \%$ of the predicted levels. Inter-species difference was expected due to the different CSF compositions but the aCSF was able to cover these with 20\% margin. Remaining peptides from Table 5 were excluded for testing because of experimentally observed interference (see ESM). For the same reason, it was not possible to estimate concentrations below $500 \mathrm{ng} / \mathrm{mL}$ using a common signature peptide as interference became significant. It should be noted that lower levels of hIgG were correctly estimated for all species by using different signature peptides optimized for each species.

\section{Conclusion}

Our findings reveal that in a bottom-up LC-MS analysis of a model $\mathrm{mAb}(\mathrm{hIgG})$, it is recommended to use a BSA solution in the range of 300 to $2000 \mu \mathrm{g} / \mathrm{mL}$ to replicate the analytical response in rat CSF. Plasma dilutions of 0.5 to $2 \%$ can also be used as an adequate aCSF matrix; however, the BSA matrix likely offers less variation and less chance of interference from endogenous proteins. The highest protein concentration of $10,000 \mu \mathrm{g} / \mathrm{mL}$ BSA also provided similar accuracy to other matrices, but the signal intensities were noticeably lower which can be expected to decrease sensitivity. Matrices with particularly low protein concentration underestimated hIgG levels when compared with real CSF and must be avoided.

The bottom-up LC-MS method used here for quantification of $\mathrm{mAbs}$ provides the ability to accurately measure $10 \mathrm{ng} / \mathrm{mL}$ hIgG in sample volumes of $10 \mu \mathrm{L}$ rat CSF or aCSF with no additional sample cleanup after digestion. The investigated aCSF could be applied to species other than rat, as shown with standards prepared in $1000 \mu \mathrm{g} / \mathrm{mL}$ BSA that was able to quantify hIgG in CSF from rat, dog, and monkey within $20 \%$ of the true concentration. It is highly plausible that other species can be included as the investigated matrices covered a large range of protein contents $(20-10,000 \mu \mathrm{g} / \mathrm{mL})$ to account for any biological variation within or between species. We hypothesize that the identified aCSF compositions that yielded reasonable results for $\mathrm{mAb}$ analysis in the current study may also be useful for quantitative analysis of other biotherapeutics or protein biomarkers in CSF where digestion efficiency and NSB are important factors. 
Table 7 Various aCSF

compositions spiked with hIgG $(n=4)$ to determine the effect on the response. The estimation is performed using a calibration curve in $1000 \mu \mathrm{g} / \mathrm{mL}$ BSA.

Concentrations estimates of hIgG are based on the ALPAPIEK 419 654 peptide fragment with $20 \mu \mathrm{L}$ injections. The total protein amount is derived from theoretical values

\begin{tabular}{|c|c|c|c|c|c|}
\hline Matrix & $\begin{array}{l}\text { Total protein in } \\
\text { matrix }(\text { pr. } 10 \mu \mathrm{L})\end{array}$ & $\begin{array}{l}\text { QC conc } \\
(\mathrm{ng} / \mathrm{mL})\end{array}$ & $\begin{array}{l}\text { Mean cal. } \\
\text { conc }(\mathrm{ng} / \mathrm{mL})\end{array}$ & $\% \mathrm{CV}$ & Mean accuracy $(\%)$ \\
\hline \multirow[t]{5}{*}{ Rat CSF } & \multirow[t]{5}{*}{$3-7 \mu \mathrm{g}$} & 10 & 10.0 & 9.0 & 100 \\
\hline & & 50 & 56.5 & 4.6 & 113 \\
\hline & & 100 & 127.2 & 6.6 & 127 \\
\hline & & 500 & 493.9 & 4.3 & 98 \\
\hline & & 1000 & 1103.0 & 2.6 & 110 \\
\hline \multirow[t]{3}{*}{$20 \mu \mathrm{g} / \mathrm{mL}$ BSA } & \multirow[t]{3}{*}{$0.2 \mu \mathrm{g}$} & 10 & 7.0 & 8.6 & 70 \\
\hline & & 100 & 73.4 & 5.1 & 73 \\
\hline & & 1000 & 786.6 & 8.3 & 79 \\
\hline \multirow[t]{3}{*}{$300 \mu \mathrm{g} / \mathrm{mL}$ BSA } & \multirow[t]{3}{*}{$3 \mu \mathrm{g}$} & 10 & 8.2 & 9.0 & 82 \\
\hline & & 100 & 82.0 & 1.7 & 82 \\
\hline & & 1000 & 865.2 & 5.9 & 87 \\
\hline \multirow[t]{3}{*}{$600 \mu \mathrm{g} / \mathrm{mL}$ BSA } & \multirow[t]{3}{*}{$6 \mu \mathrm{g}$} & 10 & 10.5 & 12.6 & 105 \\
\hline & & 100 & 96.5 & 4.8 & 96 \\
\hline & & 1000 & 945.7 & 8.5 & 95 \\
\hline \multirow[t]{3}{*}{$1000 \mu \mathrm{g} / \mathrm{mL}$ BSA } & \multirow[t]{3}{*}{$10 \mu \mathrm{g}$} & 10 & 8.6 & 9.5 & 86 \\
\hline & & 100 & 94.1 & 3.4 & 94 \\
\hline & & 1000 & 957.6 & 5.0 & $96 \%$ \\
\hline \multirow[t]{3}{*}{$1400 \mu \mathrm{g} / \mathrm{mL}$ BSA } & \multirow[t]{3}{*}{$14 \mu \mathrm{g}$} & 10 & 9.3 & 8.1 & 93 \\
\hline & & 100 & 83.6 & 2.4 & 84 \\
\hline & & 1000 & 996.8 & 8.8 & 100 \\
\hline \multirow[t]{3}{*}{$2000 \mu \mathrm{g} / \mathrm{mL}$ BSA } & \multirow[t]{3}{*}{$20 \mu \mathrm{g}$} & 10 & 9.4 & 15.1 & 94 \\
\hline & & 100 & 98.8 & 3.8 & 99 \\
\hline & & 1000 & 1036.4 & 6.1 & 104 \\
\hline \multirow[t]{3}{*}{$10000 \mu \mathrm{g} / \mathrm{mL}$ BSA } & \multirow[t]{3}{*}{$100 \mu \mathrm{g}$} & 10 & 9.8 & 14.80 & 98 \\
\hline & & 100 & 88.3 & 5.32 & 88 \\
\hline & & 1000 & 1057.6 & 3.30 & 106 \\
\hline \multirow[t]{3}{*}{$0.5 \%$ rat plasma } & \multirow[t]{3}{*}{$3 \mu \mathrm{g}$} & 10 & 8.2 & 8.8 & 82 \\
\hline & & 100 & 86.5 & 11.8 & 87 \\
\hline & & 1000 & 979.3 & 5.3 & 98 \\
\hline \multirow[t]{3}{*}{$2 \%$ rat plasma } & \multirow[t]{3}{*}{$12 \mu \mathrm{g}$} & 10 & 12.7 & 6.3 & 127 \\
\hline & & 100 & 102.8 & 4.4 & 103 \\
\hline & & 1000 & 1096.8 & 5.4 & 110 \\
\hline
\end{tabular}

$500 \mathrm{ng} / \mathrm{mL}$
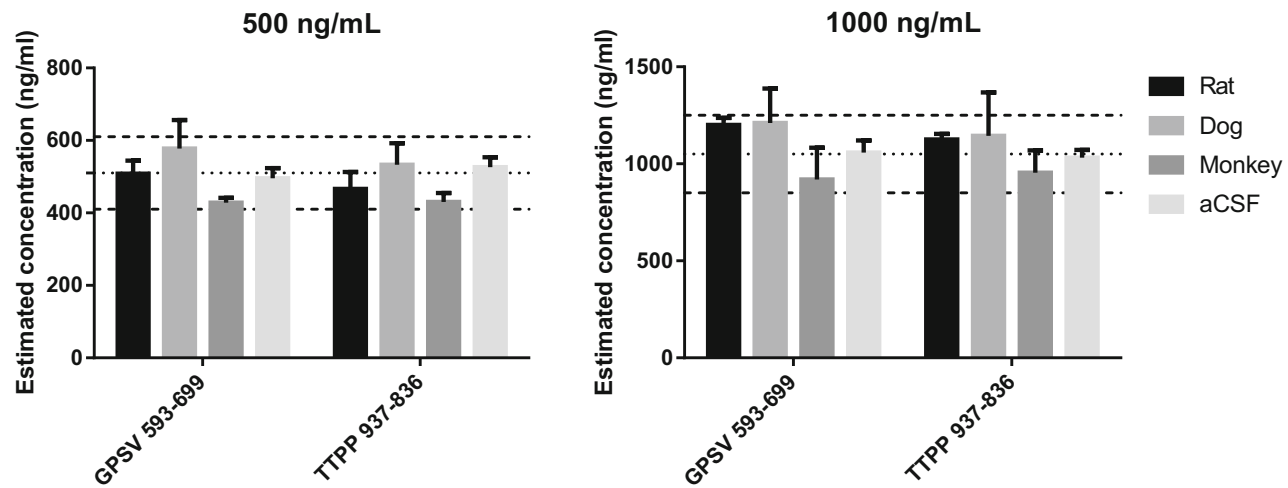

TTPPVLDSDGSFFLYSK peptides in a $1000 \mu \mathrm{g} / \mathrm{mL}$ BSA matrix calibration curve. Dotted lines mark the mean and $\pm 20 \%$ variation for the aCSF estimates
Fig. 2 Mean and standard deviation for hIgG spiked in $500 \mathrm{ng} / \mathrm{mL}$ and $1000 \mathrm{ng} / \mathrm{mL}$ in aCSF $(1000 \mu \mathrm{g} / \mathrm{mL}$ BSA $)$ and CSF from three species: rat, dog (beagle), and cynomolgus monkey (Cyno) $(n=4)$. The estimated concentrations were based on fragments of the GPSVFPLAPSSK and 
Funding information This project received financial support from the Innovation Fund Denmark through the industrial $\mathrm{PhD}$ programme.

\section{Compliance with ethical standards}

Conflict of interest The authors declare that they have no conflict of interest.

Open Access This article is licensed under a Creative Commons Attribution 4.0 International License, which permits use, sharing, adaptation, distribution and reproduction in any medium or format, as long as you give appropriate credit to the original author(s) and the source, provide a link to the Creative Commons licence, and indicate if changes were made. The images or other third party material in this article are included in the article's Creative Commons licence, unless indicated otherwise in a credit line to the material. If material is not included in the article's Creative Commons licence and your intended use is not permitted by statutory regulation or exceeds the permitted use, you will need to obtain permission directly from the copyright holder. To view a copy of this licence, visit http://creativecommons.org/licenses/by/4.0/.

\section{References}

1. Blankenship K. The top 20 drugs by 2018 U.S. sales FiercePharma. FiercePharma.2019 [cited 2019 Dec 12]. available from: https://www.fiercepharma.com/special-report/top-20-drugsby-2018-u-s-sales.

2. Li F, Fast D, Michael S. Absolute quantitation of protein therapeutics in biological matrices by enzymatic digestion and LC-MS. Bioanalysis. 2011;3(21):2459-80. https://doi.org/10.4155/bio.11. 237.

3. Lee JW. ADME of monoclonal antibody biotherapeutics: knowledge gaps and emerging tools. Bioanalysis. 2013;5(16):2003-14. https://doi.org/10.4155/bio.13.144.

4. Snyder SW, Ladror US, Wade WS, Wang GT, Barrett LW, Matayoshi ED, et al. Amyloid-beta aggregation: selective inhibition of aggregation in mixtures of amyloid with different chain lengths. Biophys J. 1994;67(3):1216-28. https://doi.org/10.1016/ S0006-3495(94)80591-0.

5. Musiek ES, Holtzman DM. Three dimensions of the amyloid hypothesis: time, space, and "wingmen". Nat Neurosci. 2015;18(6): 800-6. https://doi.org/10.1038/nn.4018.Three.

6. Selkoe DJ, Hardy J. The amyloid hypothesis of Alzheimer's disease at 25 years. EMBO Mol Med. 2016;8(6):595-608. https://doi.org/ 10.15252/emmm.201606210.

7. Alonso AC, Zaidi T, Grundke-Iqbal I, Iqbal K. Role of abnormally phosphorylated tau in the breakdown of microtubules in Alzheimer disease. Proc Natl Acad Sci. 2006;91:5562-6. https://doi.org/10. 1073/pnas.91.12.5562.

8. Stoothoff WH, Johnson GVW. Tau phosphorylation: physiological and pathological consequences. Biochim Biophys Acta. 2005;1739(2-3):280-97. https://doi.org/10.1016/j.bbadis.2004.06. 017.

9. Reiber H, Felgenhauer K. Protein transfer at the blood cerebrospinal fluid barrier and the quantitation of the humoral immune response within the central nervous system. Clin Chim Acta. 1987;163(3):319-28. https://doi.org/10.1016/0009-8981(87) 90250-6.

10. Shah DK, Betts AM. Antibody biodistribution coefficients. MAbs. 2013 [cited 2019 Mar 14];5(2):297-305. https://doi.org/10.4161/ mabs.23684.
11. Nagaya Y, Nozaki Y, Kobayashi K, Takenaka O, Nakatani Y, Kusano K, et al. Utility of cerebrospinal fluid drug concentration as a surrogate for unbound brain concentration in nonhuman primates. Drug Metab Pharmacokinet. 2014;29(5):419-26. https://doi. org/10.2133/dmpk.DMPK-14-RG-026.

12. Wang Q, Delva L, Weinreb PH, Pepinsky RB, Graham D, Veizaj E, et al. Monoclonal antibody exposure in rat and cynomolgus monkey cerebrospinal fluid following systemic administration. Fluids Barriers CNS. 2018;15(1):1-10. https://doi.org/10.1186/s12987018-0093-6.

13. Noguchi Y, Kato M, Ozeki K, Ishigai M. Pharmacokinetics of an intracerebroventricularly administered antibody in rats. MAbs. 2017;9(7):1210-5. https://doi.org/10.1080/19420862.2017. 1345834.

14. Yu YJ, Atwal JK, Zhang Y, Tong RK, Wildsmith KR, Tan C, et al. Therapeutic bispecific antibodies cross the blood-brain barrier in nonhuman primates. Sci Transl Med. 2014;6(261). https://doi.org/ 10.1126/scitranslmed.3009835.

15. Lee MS, Ji QC, editors. Protein analysis using mass spectrometry: accelerating protein biotherapeutics from lab to patient. Hoboken: Wiley; 2017. 1-258 p. Chapter: 11. https://doi.org/10.1002/ 9781119371779.

16. van den Broek I, Niessen WMA, van Dongen WD. Bioanalytical LC-MS/MS of protein-based biopharmaceuticals. J Chromatogr B Anal Technol Biomed Life Sci. 2013;929:161-79. https://doi.org/ 10.1016/j.jchromb.2013.04.030.

17. Hopfgartner G, Lesur A, Varesio E. Analysis of biopharmaceutical proteins in biological matrices by LC-MS/MS II. LC-MS/MS analysis [Internet]. Vol. 48, TrAC - Trends Anal Chem. Elsevier; 2013 [cited 2017 Oct 19]. p. 52-61. https://doi.org/10.1016/j.trac.2013. 03.008 .

18. Li H, Ortiz R, Tran L, Hall M, Spahr C, Walker K, et al. General LC-MS/MS method approach to quantify therapeutic monoclonal antibodies using a common whole antibody internal standard with application to preclinical studies. Anal Chem. 2012;84(3):1267-73. https://doi.org/10.1021/ac202792n.

19. Becher F, Ciccolini J, Imbs D-C, Marin C, Fournel C, Dupuis C, et al. A simple and rapid LC-MS/MS method for therapeutic drug monitoring of cetuximab: a GPCO-UNICANCER proof of concept study in head-and-neck cancer patients. Sci Rep. 2017;7(1):2714 . https://doi.org/10.1038/s41598-017-02821-x.

20. Kramer G, Woolerton Y, van Straalen JP, Vissers JPC, Dekker N, Langridge JI, et al. Accuracy and reproducibility in quantification of plasma protein concentrations by mass spectrometry without the use of isotopic standards. PLoS One. 2015;10(10):e0140097. https://doi.org/10.1371/journal.pone.0140097.

21. Shi J, Zheng YZ, Sin DD, DeMarco ML. A streamlined method for quantification of apolipoprotein A1 in human plasma by LC-MS/ MS. Clin Chem. 2018;64(12):1782 LP-1784. https://doi.org/10. 1373/clinchem.2018.293530.

22. Lanshoeft C, Wolf T, Heudi O, Cianférani S, Barteau S, Walles M, Picard F, Kretz O. The use of generic surrogate peptides for the quantitative analysis of human immunoglobulin G1 in pre-clinical species with high-resolution mass spectrometry. 2016;1687-99. https://doi.org/10.1007/s00216-015-9286-x.

23. Nguyen TTTN, Mistarz UH, Costa N, Herbet A, Boquet D, Becher $\mathrm{F}$, et al. Investigating the utility of minimized sample preparation and high-resolution mass spectrometry for quantification of monoclonal antibody drugs. J Pharm Biomed Anal. 2018;159:384-92. https://doi.org/10.1016/j.jpba.2018.07.012.

24. Teunissen CE, Petzold A, Bennett JL, Berven FS, Brundin L, Comabella M,Franciotty D, Frederiksen JL, Fleming JO, Furlan R, Hintzen RQ, Hughes SG, Johnson MH, Krasulova E, Kuhle J, Magnone MC, Rajda C, Rejdak K, Schmidt HK, van Pesch V, Waubant E, Wolf C, Giovannoni G, Hemmer B., Tumani H, Deisenhammer F. A consensus protocol for the standardization of 
cerebrospinal fluid collection and biobanking. Neurology. 2009 [cited 2017 Jan 17];73(22):1914-22. https://doi.org/10.1212/ WNL.0b013e3181c47cc2.

25. Pardridge WM. Drug transport in brain via the cerebrospinal fluid. Fluids Barriers CNS. 2011;8(1):7. https://doi.org/10.1186/20458118-8-7.

26. Shen DD, Artru AA, Adkison KK. Principles and applicability of CSF sampling for the assessment of CNS drug delivery and pharmacodynamics. Adv Drug Deliv Rev. 2004 [cited 2017 Sep 6];56(12):1825-57. https://doi.org/10.1016/j.addr.2004.07.011.

27. Olsson B, Lautner R, Andreasson U, Öhrfelt A, Portelius E, Bjerke $\mathrm{M}$, et al. CSF and blood biomarkers for the diagnosis of Alzheimer's disease: a systematic review and meta-analysis. Lancet Neurol. 2016;15(7):673-84. https://doi.org/10.1016/ S1474-4422(16)00070-3.

28. Blennow K, Hampel H. CSF markers for incipient Alzheimer's disease. Lancet Neurol. 2003 [cited 2018 Jul 4];2(10):605-13. https://doi.org/10.1016/S1474-4422(03)00530-1.

29. Deisenhammer F, Bartos A, Egg R, Gilhus E, Giovannoni G, Rauer $\mathrm{S}$, et al. EFNS Tast Force. Guidelines on routine cerebrospinal fluid analysis. Report from an EFNS task force. Eur J Neurol. 2006;13(9):913-22. https://doi.org/10.1111/j.1468-1331.2006. 01493.x.

30. Hooshfar S, Basiri B, Bartlett MG. Development of a surrogate matrix for cerebral spinal fluid for liquid chromatography/mass spectrometry based analytical methods. Rapid Commun Mass Spectrom. 2016;30(7):854-8. https://doi.org/10.1002/rcm.7509.

31. Maurer MH. Proteomics of brain extracellular fluid (ECF) and cerebrospinal fluid (CSF). Mass Spectrom Rev. 2010 [cited 2018 Jul 4];29(1):17-28. https://doi.org/10.1002/mas.20213.

32. Speicher KD, Kolbas O, Harper S, Speicher DW. Systematic analysis of peptide recoveries from in-gel digestions for protein identifications in proteome studies. J Biomol Tech. 2000 [cited $2018 \mathrm{Mar}$ 13];11(2):74-86. available from: https://www.ncbi.nlm.nih.gov/ pmc/articles/PMC2291619/pdf/v011p00074.pdf.

33. Granvogl B, Plöscher M, Eichacker LA. Sample preparation by ingel digestion for mass spectrometry-based proteomics. Anal Bioanal Chem. 2007 [cited 2018 Mar 13];389(4):991-1002. https://doi.org/10.1007/s00216-007-1451-4.

34. Lame ME, Chambers EE, Blatnik M. Quantitation of amyloid beta peptides $A \beta 1-38, A \beta 1-40$, and $A \beta 1-42$ in human cerebrospinal fluid by ultra-performance liquid chromatography-tandem mass spectrometry. Anal Biochem. 2011 [cited 2018 May 29];419(2): 133-9. https://doi.org/10.1016/j.ab.2011.08.010.

35. Dillen L, Cools W, Vereyken L, Timmerman P. A screening UHPLC-MS/MS method for the analysis of amyloid peptides in cerebrospinal fluid of preclinical species. Bioanalysis. 2010;3(1): 45-55. https://doi.org/10.4155/bio.10.163.

36. Barthélemy NR, Fenaille F, Hirtz C, Sergeant N, Schraen-Maschke S, Vialaret J, Buée L, Gabelle A, Junot C, Lehmann S, Becher F. Tau protein quantification in human cerebrospinal fluid by targeted mass spectrometry at high sequence coverage provides insights into its primary structure heterogeneity. J Proteome Res. 2016 [cited 2017 Feb 3];15(2):667-76. https://doi.org/10.1021/acs.jproteome. $5 \mathrm{~b} 01001$.

37. Oe T, Ackermann BL, Inoue K, Berna MJ, Garner CO, Gelfanova V, Dean RA, Siemers ER, Holtzman DM, Farlow MR, Blair IA. Quantitative analysis of amyloid $\beta$ peptides in cerebrospinal fluid of Alzheimer's disease patients by immunoaffinity purification and stable isotope dilution liquid chromatography/negative electrospray ionization tandem mass spectrometry. Rapid Commun Mass Spectrom. 2006 [cited 2018 May 29];20(24):3723-35. https://doi. org $/ 10.1002 / \mathrm{rcm} .2787$.

38. Oeckl P, Steinacker P, Otto M. Comparison of internal standard approaches for SRM analysis of alpha-synuclein in cerebrospinal fluid. J Proteome Res. 2017 [cited 2018 Jan 16];acs.jproteome.7b00660. https://doi.org/10.1021/acs.jproteome.7b00660.

39. Goda R, Murayama N, Fujimaki Y, Sudo K. Simple and sensitive liquid chromatography-tandem mass spectrometry method for determination of the $\mathrm{S}(+)$ - and $\mathrm{R}(-)$-enantiomers of baclofen in human plasma and cerebrospinal fluid. J Chromatogr B. 2004;801(2): 257-64. https://doi.org/10.1016/j.jchromb.2003.11.025.

40. Oka K, Yamamoto M, Nonaka T, Tomonaga M. The significance of artificial cerebrospinal fluid as perfusate and endoneurosurgery. Neurosurgery. 1996;38(4):733-6. https://doi.org/10.1227/ 00006123-199604000-00019.

41. Hayirli A, Grummer RR, Nordheim EV, Crump PM. Animal and dietary factors affecting feed intake during the prefresh transition period in Holsteins. J Dairy Sci. 2010;85(12):3430-43. https://doi. org/10.3168/jds.s0022-0302(02)74431-7.

Publisher's note Springer Nature remains neutral with regard to jurisdictional claims in published maps and institutional affiliations. 